\title{
Age Influence on Sexual Behavior of the Lesser Cornstalk Borer, Elasmopalpus lignosellus (Zeller) (Lepidoptera: Pyralidae)
}

\author{
LMS XaVier ${ }^{1,2}$, DM Magalhães ${ }^{1}$, PA Viana ${ }^{3}$, MC Blassioli-Moraes ${ }^{1}$, M Borges ${ }^{1}$, JAF Barrigossi ${ }^{4}$, \\ EF VILELA ${ }^{2}$, RA LAUMANN ${ }^{1}$
}

${ }^{1}$ Lab de Semioquímicos, Embrapa Recursos Genéticos e Biotecnologia, Brasilia, DF, Brasil

${ }^{2}$ Depto de Biologia Animal, Univ Federal de Viçosa, Viçosa, MG, Brasil

${ }^{3}$ Embrapa Milho e Sorgo, Sete Lagoas, MG, Brasil

${ }^{4}$ Embrapa Arroz e Feijão, Santo Antônio de Goiás, Goiás, Brasil

\section{Keywords}

Reproductive maturity, chemical communication, moth, attraction, sexual receptivity

\section{Correspondence}

RA Laumann, Lab de Semioquímicos, Embrapa Recursos Genéticos e Biotecnologia, Brasilia, DF, Brasil; raul. laumann@embrapa.br

Edited by Andres Gonzáles - Univ de la República, Uruguay

Received 14 June 2016 and accepted 7 April 2017

Published online: 4 May 2017

(C) Sociedade Entomológica do Brasil 2017

\begin{abstract}
The objective of this work was to evaluate the reproductive behavior and response of Elasmopalpus lignosellus (Zeller) males to calling females. Frequency of mating was recorded in couples during the first 7 days of the adult stage. Calling behavior of females was observed during the first 4 days of the adult stage and responses of males, in the same age intervals, to calling females were recorded in wind tunnel bioassays. The maximum number of matings occurred when the couple was between 24 and $48 \mathrm{~h}$ old. The scotophase period significantly influenced mating behavior, which peaked between 6 and $8 \mathrm{~h}$ of darkness and the mean mating duration was $93.9 \pm 4.2 \mathrm{~min}$. Calling females, when evaluated in a wind tunnel, attracted significantly more males than in bioassays with clean air (control). The number of individuals in calling behavior was significantly lower for females that were between o to $24 \mathrm{~h}$ old compared to the other females evaluated, but this did not influence male response. A lower proportion of males between 48 to $72 \mathrm{~h}$ old responded to calling females and these responses were delayed in comparison with males of other ages (o to 24,24 to 48 , and 72 to $96 \mathrm{~h}$ old). These results indicate that the age of E. lignosellus males influences the response to conspecific calling females.
\end{abstract}

\section{Introduction}

The lesser cornstalk borer (LCB), Elasmopalpus lignosellus (Zeller) (Lepidoptera: Pyralidae), is an important insect pest widely distributed in the tropical and temperate regions of the western hemisphere from the south of the USA to Argentina and Chile. More than 60 species of host crops have been described for the LCB (Stone 1968, Viana 2004). This insect is a serious pest in Brazil, especially in maize, soybean, cotton, rice, sorghum, wheat, peanut, and sugarcane (Viana 2004). The larvae of $E$. lignosellus feed on plants up to $30 \mathrm{~cm}$ in height (Pinto et al 2004), boring a tunnel into the plant stem that can kill the host when it reaches the apical meristem, often known as dead heart (Pinto et al 2004).
The sex pheromone of LCB from a North American population (USA) was identified as a mixture of (Z)-7-tetradecenyl acetate, (Z)-9-tetradecenyl acetate, (Z)-9-tetradecenol, and (Z)-11-hexadecenyl acetate (proportion 37:20:4:39), and activity of this mixture was confirmed in a field test (Lynch et al 1984). However, this mixture failed to attract males of $L C B$ in Brazil (Pires et al 1992). The chemical analysis of the sex pheromone of Brazilian populations from Goiânia (Goias State), Sete Lagoas (Minas Gerais State) (Lynch et al 1984, Jham et al 2005, 2007), and Paraná State (de Viana 2015) identified a specific blend of $E$. lignosellus for each population, which was different from that of the North American population.

The effective population monitoring of $E$. lignosellus with the use of sex pheromone could help develop IPM strategies 
for this pest in Brazil. To do this, it is necessary to identify the specific sex pheromone blend for the Brazilian populations of this pest. In moths, variability of the sex pheromone blend between populations, the circadian dynamics of female signaling and male response to pheromones are factors that should be considered to understand the sexual communication and selection process (Ma et al 2015, Groot 2014, Groot et al 2016).

Pires et al (1994) observed that LCB female calling behavior starts on the first night of becoming an adult, and $70 \%$ of females called at least once during the second night. These authors also found that scotophase influences calling behavior that is limited to the second half of the dark phase and is influenced by age; older females start their calling earlier. However, there is no information about the influence of male age on the behavioral response to the female sex pheromone, which is important because traps with the sex pheromone can be employed to monitor the male population. In this study, an evaluation was carried out on LCB reproductive behavior and the male response to calling females in a wind tunnel. The aim of this work is to answer two questions: (1) what are the periodicity, the duration and the age at which mating occurs? (2) Is the frequency of male responses to calling females related to their age?

\section{Material and Methods}

\section{Insects}

A laboratory colony of E. lignosellus started at Embrapa Genetic Resources and Biotechnology (Brasília, Brazil), from insects of a mass rearing at Embrapa Milho e Sorgo (Sete Lagoas, Minas Gerais State) that was originally collected in sugarcane fields in Viçosa (Minas Gerais State, Brazil, $20^{\circ} 45^{\prime}$ $\left.S, 42^{\circ} 52^{\prime} \mathrm{W}\right)$. The larvae were reared on an artificial diet (Chalfant 1975), modified by Viana (1993), maintained at $28.0 \pm 0.5^{\circ} \mathrm{C}$, and $70 \pm 10 \%$ r.h., under a reversed photoperiod of L12:D12 (scotophase starting at 6:00 am). All the experiments with $E$. lignosellus in this work were carried with individuals from ten laboratory generations.

\section{Periodicity and length of mating}

To assess the periodicity and length of mating, 60 couples of E. lignosellus were placed individually into plastic pots within $2 \mathrm{~h}$ after adult emergence, fed with an alcohol-free beer, and maintained in a separate room in the same environmental conditions as described above for larval rearing. The couples were monitored by direct observation during the scotophase of the reversed photoperiod previously described, during 7 days (o to $168 \mathrm{~h}$ old) after adult emergence. Scotophase observations were conducted using fluorescent red light $(40 \mathrm{~W})$ in intervals of $5 \mathrm{~min}$. The observations were grouped in periods of 2 hours. Therefore, for a scotophase of $12 \mathrm{~h}$, the observations were grouped into six periods. The start of mating and mating duration were registered.

\section{Wind tunnel bioassays}

Behavioral tests were carried out in a wind tunnel to evaluate orientation of virgin males towards virgin calling females. The wind tunnel was constructed with a glass cylinder with a flight section of $120 \mathrm{~cm} \times 10 \mathrm{~cm}$ internal diameter. Airflow was produced by two computer fans $(15 \mathrm{~cm}$ diameter), one at the up-wind extremity of the glass cylinder to create the airflow, and the other at the opposite side, working as an exhaust. Prior to the up-wind fan, the incoming air was driven by a cylinder ( $15 \mathrm{~cm}$ diameter $\times 5 \mathrm{~cm}$ long) with activated charcoal. To create a laminar flow, a cardboard "honey comb" circle $(3 \mathrm{~cm} \times 15 \mathrm{~cm}$ diameter) was adapted to the up-wind fan. The wind speed was calibrated at $0.5 \mathrm{~m} / \mathrm{s}$.

All bioassays were performed under the scotophase of the reversed photoperiod (12L:12D), between 4 to $12 \mathrm{~h}$ after the initiation of the scotophase, and in the same environmental conditions described above for larval rearing. The wind tunnel was illuminated from above with two $40 \mathrm{~W}$ fluorescent red lights. The males were grouped within age classes of 0 to 24 , 24 to 48,48 to 72 , and 72 to $96 \mathrm{~h}$ old (hours after adult emergence). Their orientation to virgin calling females of the same age classes in all combinations of male and female ages was evaluated. Fifteen females of the same age class were placed inside a plastic cylinder cage $(8 \times 20 \mathrm{~cm}$ diameter to length) with the open ends closed with a voile cloth, which was placed inside the wind tunnel in front of the air entrance. The plastic cage was arranged with its open ends in the same direction of the airflow. At least 40 bioassays were performed for each combination of male and female age. Additionally, control bioassays were performed using the plastic cages without females ( $N=10$ for each male age). The males were released individually at the downwind extremity of the wind tunnel, $1 \mathrm{~m}$ away from caged females. The males were placed in a plastic cylinder $(6 \mathrm{~cm} \times 3 \mathrm{~cm}$ diameter) with its ends closed with cotton wads and maintained in the same environmental conditions for $10 \mathrm{~min}$ before its use in the bioassays. After this time, the cylinder was introduced into the wind tunnel and the cotton wads were removed gently.

The males inside the wind tunnel were observed for 10 min recording the vibration of wings or antennae and direct flight or walk to the odor source. Since this small moth naturally performs short and erratic flights (Xavier, LMS and Laumann, RA, field observations), a response in the wind tunnel was considered positive when the males left the liberation point and flew up-wind, reaching at least half distance to the caged females. For males that showed a positive response, the activation time (time since the males were introduced in the wind tunnel to when they left the 
liberation area flying or walking) was also registered. In addition, during this set of bioassays, we recorded the number of females, in each group and age class, with their typical calling behavior (female at rest with open wings and abdomen pointing upwards).

\section{Statistical analysis}

Chi-square $\left(\chi^{2}\right)$ tests were performed to analyze the differences in the number of couples mating, considering different periods of the scotophase and age class. The response of males in the wind tunnel was analyzed using generalized linear models (GLM) and deviance analyses (ANODEV) with binominal distribution (positive responses or no response) of errors and log as link function. The model included two factors, male age class and female age class. For factors with significant effects, means were compared using contrast analyses. The activation times of males in each age class were compared using GLM and ANODEV with Gaussian errors and identity as link function followed by comparison of means using Tukey's test. To compare the number of females in calling behavior, GLM and ANODEV were used, with Poisson errors and log as link function followed by mean comparison using contrast analyses. All the analyses were carried out in software R ( $R$ statistical Development Core Team 2010) at 5\% significance level.

\section{Results}

Forty-one couples of the 60 observed mated (68.3\%). The mating distribution in relation to couple age was significantly different $\left(X_{6}{ }_{6}=59.29, P<0.05\right)$. Higher frequency $(31.9 \%)$ of mating was observed when the insects were $24-48 \mathrm{~h}$ old (Table 1). Differences in mating related to scotophase periods were significant $\left(\chi_{5}^{2}=69.07, P<0.05\right)$. The mating occurred preferentially from 6 to $8 \mathrm{~h}$ after the onset of scotophase; $68.3 \%$ of mating was observed in this period (Table 2). Courtship behavior in males is characterized by wing fanning when a female approaches. The mean mating duration was $93.9 \pm 4.2 \mathrm{~min}$.

The age of males influence their responses to calling females (ANODEV, $\chi_{3}^{2}=9.06, P=0.03, \mathrm{df}=3$ ), while female age did not show a significant effect on male response (ANODEV, $\chi_{3}^{2}=1.92, P=0.59, \mathrm{df}=3$ ). In addition, there were no significant interactions between male and female age (ANODEV, $\chi^{2}{ }_{9}=14.46, P=0.11, \mathrm{df}=9$ ). . Considering this result, the responses of males from different age classes were analyzed independently of the female age class. Males within 48-72 h old show a lower response level (Fig 1). Only 7.5\% of males ( 3 of 40 ), considering all age classes, introduced in the wind tunnel without females (control) left the plastic tube and moved up in the wind tunnel.
Table 1 Percentage of Elasmopalpus lignosellus couples that mated at different age intervals ( $0-168 \mathrm{~h}$ after emergence) during scotophase of a photoperiod of 12L:12D $(N=60)$.

\begin{tabular}{ll}
\hline Age of couples in hours & Couples mating (\%) \\
\hline $0-24$ & 7.3 \\
$24-48$ & 31.9 \\
$48-72$ & 17.0 \\
$72-96$ & 7.7 \\
$96-120$ & 6.5 \\
$120-144$ & 4.2 \\
$144-168$ & 0.0 \\
Total mating & 68.3 \\
\hline
\end{tabular}

The mating distribution in relation to couple age was significantly different $\left(\chi_{6}^{2}=59.29, P<0.05\right)$.

Similarly, the mean for activation time showed significant variation only according to the age of males $\left(F_{3,177}=7.78\right.$, $P<0.05)$. Males that were $48-72 \mathrm{~h}$ old showed a higher activation time than the other ages evaluated (Fig 2).

The mean number of calling females in wind tunnel tests, for the four ages analyzed, differed significantly (ANODEV, $\chi_{3}^{2}=124.25, P<0.01, \mathrm{df}=3$ ). The females between 0 to $24 \mathrm{~h}$ old showed significantly lower frequency in calling behavior compared to the other females evaluated (Fig 3). On the other hand, females that were 72-96 $\mathrm{h}$ old had higher number of females in calling behavior (Fig 3).

Of the 110 males observed, $100 \%$ of them vibrated their antennae after being introduced in the wind tunnel, 7.3\% fanned their wings, $56.4 \%$ flew directly to the odor source, $26.4 \%$ walked linearly towards the females, $3.6 \%$ walked in circles, and $38.2 \%$ walked in zigzag movements to the odor source.

\section{Discussion}

The lesser cornstalk borer showed mating peaks when the adults were between 24 and $48 \mathrm{~h}$ old; the highest frequency of mating was observed between 6 to $8 \mathrm{~h}$ after the beginning

\begin{tabular}{lll}
\cline { 2 - 3 } Table 2 Percentage of & Hours scotophase & Couples mating (\%) \\
\cline { 2 - 3 } couples that mated at & & 0.0 \\
different periods in the & $0-2$ & 2.4 \\
scotophase & $2-4$ & 21.9 \\
(photoperiod 12L:12D) & $4-6$ & 68.3 \\
$(N=41)$. & $6-8$ & 7.3 \\
& $8-10$ & 0.0 \\
& $10-12$ &
\end{tabular}

The mating distribution in relation to scotophase periods was significantly different $\left(\chi^{2}{ }_{5}=69.07, P<0.05\right)$. 


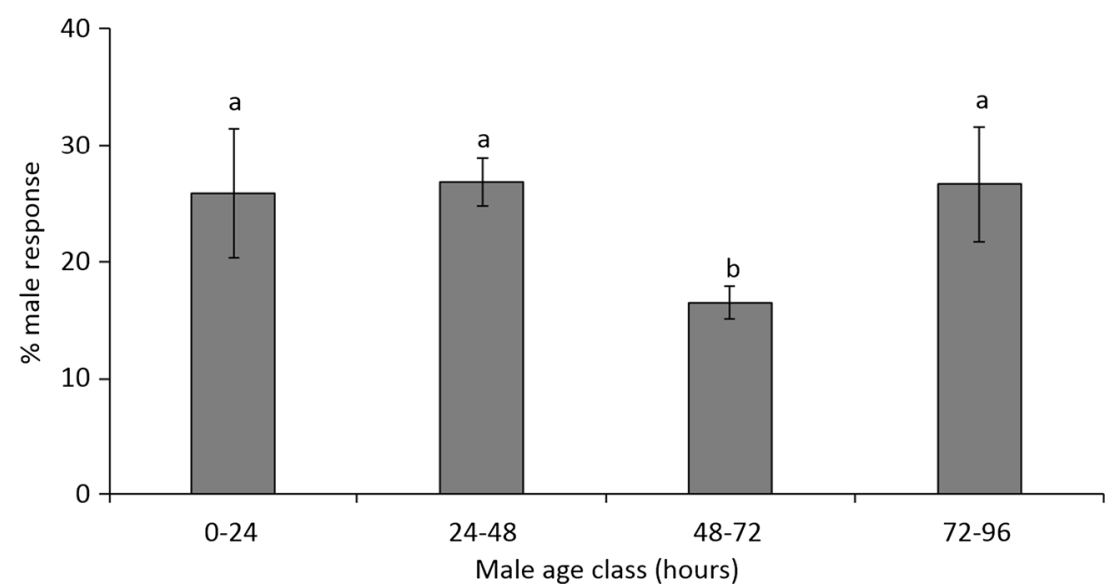

Fig 1 Percentage (mean \pm SE) of Elasmopalpus lignosellus males of four different ages attracted to calling females in wind tunnel bioassays. The bars represent the mean percentage of males of each age class responding to females of the four age classes (0-24, 24-48, 48-72, and $72-96 \mathrm{~h}, \mathrm{~N}=4 \mathrm{for}$ each male age class). Bars followed by different letters are significantly different (ANODEV, $\chi_{3}^{2}=9.06 P=0.03$, $\mathrm{df}=3$ and mean comparisons by contrast analysis $(P<0.05))$.

of the scotophase. This is directly in relation to LCB female calling behavior, which shows maximum frequency in this period of the scotophase (Pires et al 1994, de Viana 2015) and after females reach $24 \mathrm{~h}$ in adult age (Fig 3).

Pires et al (1994) and data on Fig 3 show that calling behavior of LCB females start on the first day after emergence, suggesting that they are sexually mature at this time. In this work, the maximum number of matings were observed when the insects were $24-48 \mathrm{~h}$ old, which suggests that male at this age are in optimum physiological state for reproduction, a fact also observed in other species of Pyralidae (Witethom 1992, Parra-Pedrazzolli \& Leal 2006).

In general, lepidopteran males are highly attracted to the sex pheromone of females after they become sexually mature (Baker 1989, Roelofs 1995, Jarriault et al 2009), and in some moth species, the male response to female pheromones increases with adult age (Anton \& Gadenne 1999, Gadenne \& Anton 2000, Evenden \& Gries 2008). For example, Baker \& Cardé (1979) reported the highest response to sex pheromone in Grapholita molesta Busk (Tortricidae) when males were 72 to $96 \mathrm{~h}$ old. In our wind tunnel bioassays, E. lignosellus males showed a lower level of response to calling females at $48-72 \mathrm{~h}$ old. However, males at 72-96 $\mathrm{h}$ old responded in a similar proportion as younger males, suggesting that complex physiological or behavioral mechanisms could be responsible for the alterations in the response to volatiles from calling females.

One of the explanations for these observations could be endocrinological changes, such as JH levels and the status of accessory glands, which modify the level of response to sex pheromones, as was demonstrated in other Lepidoptera (Happ 1984, 1992, Anton \& Gadenne 1999, Gadenne et al 2001, Jin \& Gong 2001, Carlsson \& Hansson 2003, Gillott 2003, Wedell 2005, Jarriault et al 2009, Soques et al 2010). Another reason could be a differential expression of odorant binding proteins related to male age, a phenomenon

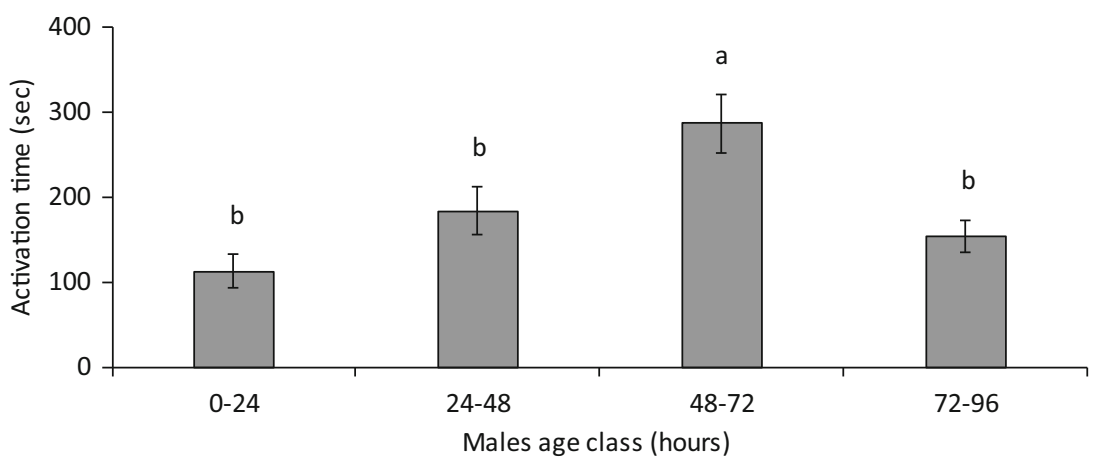

Fig 2 Activation time (sec) (mean \pm SE) of Elasmopalpus lignosellus males of four different ages when were stimulated with calling females in wind tunnel bioassays. The activation time was characterized as the time from the introduction of the males in the wind tunnel until they left the liberation area by flying or walking. The bars represent mean values of activation time for males of each age class responding to females of the four age classes

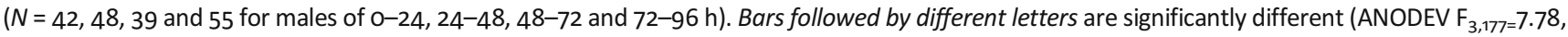
$P<0.05$ and mean comparisons by Tukey's test $(P<0.05))$. 


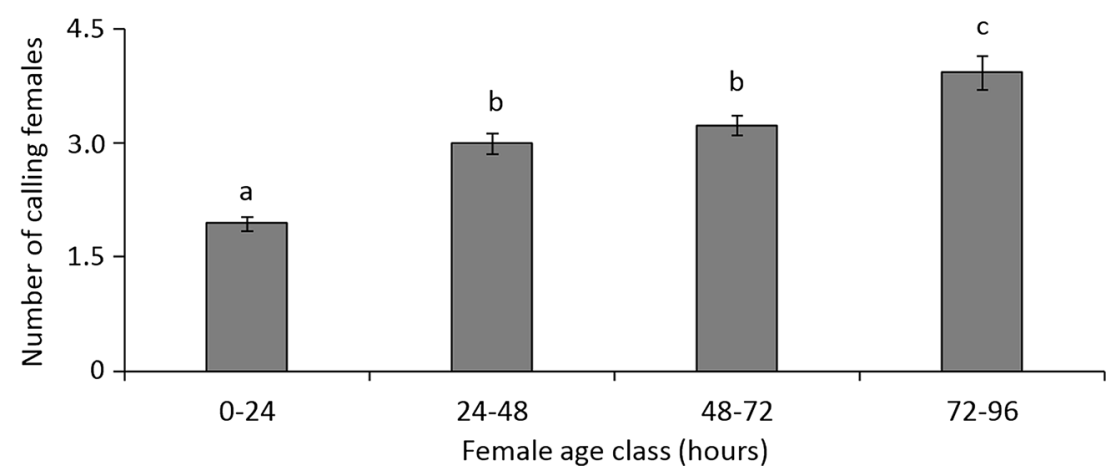

Fig 3 Number (mean \pm SE) of Elasmopalpus lignosellus calling females of different age classes. The number of calling females was counted from groups of 15 insects in wind tunnel bioassays. The number of groups observed by age class were $0-24 \mathrm{~h}=163,24-48 \mathrm{~h}=211,48-72 \mathrm{~h}=213$, and $72--$ $96 \mathrm{~h}=198$. Bars with different letters are significantly different (ANODEV, $\chi_{3}^{2}=124.25, P<0.01, \mathrm{df}=3$ ) and mean comparisons by contrast analyses $(P<0.05)$.

observed in two other pyralids, namely Orthaga achatina (Butler) (Liu et al. 2012) and Cnaphalocrocis medinalis (Guenée) (Liu et al 2015). To better understand the degree of difference in response by $E$. lignosellus males at different age classes, further studies are needed including molecular, neural, and electrophysiological techniques. Pheromone production in moths generally decreases in older females, and as a result, they spend more time in calling behavior (Groot 2014, Umbers et al 2015). In our study, the age of E. lignosellus females did not influence male attraction.

The results presented in this study under controlled conditions are in agreement with field observations in which E. lignosellus virgin females at 0 to $96 \mathrm{~h}$ old showed no significant differences in attracting males (Payne \& Smith 1975). Notwithstanding, in wind tunnel bioassays, the number of females in calling behavior increased with their age, which could be the cause for similar male attraction to different female age classes. A similar pattern of calling behavior was reported by de Viana (2015) stating that $98 \%$ of females between 48 to 72 and 96 to $120 \mathrm{~h}$ old, displayed calling behavior during the scotophase, which is in contrast with $50 \%$ of the females between 0 to $24 \mathrm{~h}$ old. In this way, an increased number of $E$. lignosellus females in calling behavior could compensate the reduction in sex pheromone production. How this could be characterized as a group strategy needs to be addressed in future works.

In this research, we observed that insect age and scotophase period influences $E$. lignosellus mating behavior. Our results indicate that males reach maximal reproductive capacity after $24 \mathrm{~h}$ into the adult stage. These observations, associated with those previously reported by Pires et al (1994) and de Viana (2015) in laboratory and field conditions, respectively, represent important information about the sexual behavior of this species.

The sex pheromone composition of $E$. lignosellus of different Brazilian populations from Goiânia (Goias State), Sete Lagoas (Minas Gerais State) (Lynch et al 1984, Jham et al 2005, 2007), and from Paraná State Viana (2015) showed a specific blend of each population. These were also different from North American population, that was described as a mixture of (Z)-7-tetradecenyl acetate, (Z)-9-tetradecenyl acetate, (Z)-9-tetradecenol, and (Z)-11-hexadecenyl acetate (proportion 37:20:4:39) (Lynch et al 1984). Studies of Brazilian populations identified the presence of $(E)$-8hexadecenyl acetate, (Z)-9-hexadecenyl acetate, and (Z)-11hexadecenyl acetate in the population from Goiânia. Only two acetates which are (Z)-9-hexadecenyl acetate and (Z)11-hexadecenyl acetate were found in the population from Sete Lagoas, and a mix of two alcohols and three acetates non-identified in the population from Paraná (Jham et al 2005, 2007, de Viana 2015). These differences could be a result of population isolation. However, host plants, climate conditions, rearing procedures, and experimental procedures in the laboratory could also contribute to originate differences in the pheromone blend.

Results presented here could be relevant in future works and may be useful in the identification of the sex pheromone blend of Brazilian populations of $E$. lignosellus and to determine biological activity of natural and synthetic sex pheromone in the laboratory.

Acknowledgements This work received financial support from the Brazilian Council for Scientific and Technological Development (CNPq), Distrito Federal Research Foundation (FAP-DF), and Brazilian Agricultural Research Corporation (EMBRAPA).

\section{References}

Anton S, Gadenne C (1999) Effect of juvenile hormone on the central nervous processing of sex pheromone in an insect. Proc Natl Acad Sci U S A 96:5764-5767

Baker TC (1989) Sex pheromone communication in the Lepidoptera: new research progress. Experientia 45:248-262

Baker TC, Cardé RT (1979) Endogenous and exogenous factors affecting periodicities of female calling and male sex pheromone response in Grapholitha milesta (Busck). J In Physiol 25:943-950 
Carlsson MA, Hansson BS (2003) Plasticity and coding mechanisms in the insect antennal lobe. In: Blonquist GJ, Vogt RG (eds) Insect pheromone biochemistry and molecular biology: the biosynthesis and detection of pheromones and plant volatiles. Elsevier Academic Press, Amsterdam, pp 669-728

Chalfant RB (1975) A simplified technique for rearing the lesser cornstalk borer (Lepidoptera: Phycitidae). J Ga Entomol Soc 10:33-37

Evenden ML, Gries R (2008) Plasticity of male response to sex pheromone depends on physiological state in a long-lived moth. An Behav 75:663-672

Gadenne C, Anton S (2000) Central processing of sex pheromone stimuli is differentially regulated by juvenile hormone in a male moth. $\mathrm{J}$ Ins Physiol 46:1195-1206

Gadenne C, Dufour MC, Anton S (2001) Transient post-mating inhibition of behavioural and central nervous responses to sex pheromone in an insect. Proc Roy Soc B 268:1631-1635

Gillott C (2003) Male accessory gland secretions: modulators of female reproductive physiology and behavior. Annu Rev Entomol 48:163-184

Groot AT (2014) Circadian rhythms of sexual activities in moths: a review. Ecol Evol 43:1-21

Groot AT, Schöfl G, Inglis O, Donnerhacke S, Classen A, Schmalz A, Santangelo RG, Emerson J, Gould F, Schal C, Heckel DG (2016) Within-population variability in a moth sex pheromone blend: genetic basis and behavioural consequences. Proc Roy Soc B 281:1-10

Happ GM (1984) Structure and development of male accessory glands in insects. In: KingRC, Akai H (eds) Insect ultrastructure. Plenum Press, London, pp 365-392

Happ GM (1992) Maturation of the male reproductive system and its endocrine regulation. Annu Rev Entomol 37:303-320

Jarriault D, Barrozo RB, de Pinto CJC, Greiner B, Dufour MC, Roca IM, Gramsbergen JB, Anton S, Gadenne C (2009) Age-dependent plasticity of sex pheromone response in the moth, Agrotis ipsilon: combined effects of octopamine and juvenile hormone. Horm Behav 56:185-191

Jham GN, da Silva AA, Lima ER, Viana P (2005) Identification (GC and GCMS) of unsaturated acetates in Elasmopalpus lignosellus and their biological activity (GC-EAD and EAG). J Sep Sci 28:281-285

Jham GN, da Silva AA, Lima ER, Viana PA (2007) Identification of acetates in Elasmopalpus lignosellus pheromone glands using a newly created mass spectral database and Kóvats retention indices. Quim Nova 30: 916-919

Jin ZY, Gong H (2001) Male accessory gland derived factors can stimulate oogenesis and enhance oviposition in Helicoverpa armigera (Lepidoptera: Noctuidae). Arch Insect Biochem Physiol 46:175-185

Liu S, Xiao-Xiao S, Zhu Q-Z, Wen-Juan J, Zhu Zi-Jie YH, Wang G-Y, Zhu Z-R (2015) Identification and expression profiles of putative chemosensory protein genes in Cnaphalocrocis medinalis (Lepidoptera: Pyralidae). J Asia Pac Entomol 18:99-105

Lynch RE, Klun JÁ, Leonhardt BA, Schwarz M, Garner JW (1984) Female sex pheromone of the lesser cornstalk borer, Elasmopalpus lignosellus (Lepidoptera: Pyralidae). Environ Entomol 13:121-126
Ma T, Liu Z, Lu J, Sun Z, Li Y, Wen X, Cui Y (2015) A key compound: (Z)-9tetradecen-1-ol as sex pheromone active component of Hypsipyla robusta (Lepidoptera: Pyralidae). Chemoecology 25:325-330

Parra-Pedrazzolli AL, Leal WS (2006) Sexual behavior of the navel orangeworm, Amyelois transitella (Walker) (Lepidoptera: Pyralidae). Neotrop Entomol 35:769-774

Payne TL, Smith JW Jr (1975) A sex pheromone in the lesser cornstalk borer. Environ Entomol 4:355-356

Pinto AS, Parra JRP, Oliveira HN (2004) Guia ilustrado de pragas e insetos benéficos do milho e sorgo. Livraria PLD, Ribeirão Preto, p 108

Pires CSS, Vilela EF, Viana PA, Ferreira JTB (1992) Avaliação no campo do feromônio sexual sintético de Elasmopalpus lignosellus (Zeller) (Lepidoptera: Pyralidae). An Soc Entomol Brasil 21:59-68

Pires CSS, Vilela EF, Viana PA (1994) Comportamento de fêmeas de Elasmopalpus lignosellus (Zeller) (Lepidoptera: Pyralidae) associado à liberação de feromônio sexual. An Soc Entomol Brasil 23:1-12

R Development Core Team (2010) R: A language and environment for statistical computing.R Foundation for Statistical Computing, Vienna, Austria. ISBN 3-900051-07-0

Roelofs WL (1995) Chemistry of sex attraction. Proc Natl Acad Sci U S A 92:44-49

Liu S-J, Liu N-Y, He P, Li Z-Q, Dong S-L (2012) Molecular characterization, expression patterns, and ligand-binding properties of two odorant binding protein genes from Orthaga achatina (Butler) (Lepidoptera: Pyralidae). Arch Insect Biochem Physiol 80:123-139

Soques S, Vásquez GM, Grozinger CM, Gould F (2010) Age and mating status do not affect transcript levels of odorant receptor genes in male antennae of Heliothis virescens and Heliothis subflexa. J Chem Ecol 36:1226-1233

Stone KJ (1968) Reproductive biology of the lesser cornstalk borer. I rearing technique. J Econ Entomol 61:1712-1714

Umbers KDL, Symonds MRE, Kokko H (2015) The mothematics of female pheromone signaling: strategies for aging virgins. Am Nat 3:417-432

Viana PA (1993) Importância econômica e bioecologia da broca Elasmopalpus lignosellus Simpósio Latino Americano de cana-deaçúcar, 2. Maceió, p.1-21

Viana PA (2004) Lagarta-elasmo,. In: Salvadori JR, Ávila CJ, Silva MTB da (ed.). Pragas de solo no Brasil. Passo Fundo: Embrapa Trigo; Dourados: Embrapa Agropecuária Oeste; Cruz Alta: Fundacep Fecotrigo, pp 379-408

Viana E S de (2015) Mudanças climáticas e feromônio sexual: novas tecnologias para o manejo de Elasmopalpus lignosellus (Zeller, 1848) (Lepidoptera: Pyralidae) em áreas agrícolas no Mato Grosso. Dissertação de Mestrado, Universidade Estadual de Mato Grosso UNEMAT, $53 \mathrm{p}$

Wedell N (2005) Female receptivity in butterflies and moths. J Exp Biol 208:3433-3440

Witethom B (1992) Effects of age on calling and matting behavior of the sapodilla fruit borer, Nephopterix sp. (Lepidoptera: Pyralidae). J Sci Soc Thailand 18:93-103 